Sains Malaysiana 49(8)(2020): 1853-1863

http://dx.doi.org/10.17576/jsm-2020-4908-08

\title{
A Review on the Association of Bacteria with Stingless Bees
}

(Suatu Ulasan tentang Perkaitan Bakteria dengan Kelulut)

\author{
Mohamad Syazwan Ngalimat, Raja Noor Zaliha Raja Abd Rahman, Mohd Termizi Yusof, Amir \\ SYAHIR AMIR HAMZAH, NORHASNIDA ZAWAWI \& SURIANA SABRI*
}

\begin{abstract}
Most cultivable microbes associated with stingless bees are bacteria. Studies about bacteria related to stingless bee colonies were only limited to bacterial isolation and identification, while a few studies consider their potential applications. Information on their biological roles and functions are scarce. Bacteria classified under the genera Bacillus, Streptomyces, and Lactobacillus are commonly associated with stingless bee colonies. They have been hypothesized to contribute to the formation and enhancement of antimicrobial activities of bee products such as honey and bee bread. There is now sizeable evidence that the microflora of bees can be used as biocontrol agent, potential probiotic, as well as producer of antimicrobial compounds and enzymes. The aim of this review was to stimulate a generation of further research on the enormous potential of the bacteria associated with stingless bees, their contributions and potential applications especially in medical and pharmaceutical uses.
\end{abstract}

Keywords: Bacteria; bee bread; bees and bacterial interaction; honey; stingless bee

\section{ABSTRAK}

Kebanyakan mikrob yang bersekutu dengan kelulut adalah bakteria. Kajian mengenai bakteria yang berkaitan dengan koloni kelulut hanya terhad kepada pemencilan dan pengecaman bakteria, sementara hanya beberapa kajian menganggap potensi aplikasi mereka. Maklumat mengenai peranan dan fungsi biologi mereka adalah terhad. Bakteria dikelaskan di bawah genus Bacillus, Streptomyces dan Lactobacillus biasanya dikaitkan dengan koloni kelulut. Mereka telah dihipotesiskan untuk menyumbang kepada pembentukan dan peningkatan aktiviti antimikrob produk-produk lebah seperti madu dan roti debunga. Terdapat bukti bahawa mikroflora lebah boleh digunakan sebagai agen kawalan bio, potensi probiotik serta pengeluar sebatian antimikrob dan enzim. Matlamat ulasan kajian ini adalah untuk merangsang satu generasi penyelidikan lanjut tentang potensi bakteria yang berkait dengan kelulut, sumbangan dan potensi mereka khususnya dalam penggunaan perubatan dan farmaseutik.

Kata kunci: Bakteria; interaksi lebah dan bakteria; kelulut; madu; roti debunga

\section{INTRODUCTION}

Stingless bees (Apidae: Meliponini) are known as 'kelulut' in Malay, Malaysia; 'klanceng' in Java, Indonesia; 'emmu' in Sulawesi, Indonesia; 'lukut' in Tagalog, Philippines; and 'damar' in Hindi, India (Jalil 2014). Stingless bees can be found in the tropical regions including the Indo-Australian, sub-Saharan African (Afrotropics) and American tropics (Neotropics). They are classified as primitive because they have a pantropical distribution of over 65 million years, which is longer than honeybees (Apidae: Apini) (Roubik 2006). Stingless bees are eusocial and their labor division is similar to that of the honeybee colony (Bassindale \& Matthews 1955). Stingless bees produce bee products including honey, bee bread and propolis (Figure 1). There are three castes in the bee colony, namely the queen, worker and drone (Wille 1983). Although stingless bees share many similarities with honeybees, there are many characteristics that have not been explored (Michener 2013).

The knowledge about microbial biodiversity on stingless bee products is very limited since most papers focus only on microbial identification but not their function. The main microbes associated with stingless bees are yeasts, molds, and bacteria (Anderson et al. 2011; Morais et al. 2013). Bacteria are the major microbes associated with stingless bees (Menezes et al. 2013). Bacteria that are found in the bee colonies are induced by direct microflora transmissions from one bee generation to the next (Sachs et al. 2011). Sources of the bacteria include pollen, air, flowers and the digestive tracts of bees. Bacteria may be present in bee products due to primary or secondary contamination from humans, equipment, 
containers, wind, and dust (Olaitan et al. 2007). Most of the bacterial genera associated with stingless bee colonies were from the genera Bacillus, Streptomyces, and Lactobacillus (Amin et al. 2020; Ngalimat et al. 2019; Promnuan et al. 2009; Pucciarelli et al. 2014; Yaacob et al. 2018).

Bacteria are commonly isolated from stingless bee products (Amin et al. 2020; Lani et al. 2017; Ngalimat et al. 2019). However, their biological roles are still unclear (Gilliam et al. 1990; Olaitan et al. 2007). Investigations on the association of bacteria with stingless bees mostly focus on bacterial identification. Fewer studies highlighted their contribution to the metabolic conversion of bee products and the protection of nests against pathogenic microorganisms. Bacteria contributed to the formation of bee products by producing various enzymes include lipases, proteases, aminopeptidases, and glycosidases, which convert raw materials of bee products into more digestible products for storage (Gilliam et al. 1990). Moreover, the bacteria presumably secrete chemicals, such as antimicrobial metabolites, to inhibit spoilage and the proliferation of competing microorganisms (Promnuan et al. 2009).

Bee products can be a good source of beneficial bacteria. Bacterial species associated with bee products have been characterized as potential biocontrol agents against pathogenic microorganisms. Evidently, Paenibacillus polymyxa ALLI-03-01 from the larval food of Melipona scutellaris acts as a biocontrol agent against entomopathogenic fungus, Beauveria bassiana (Menegatti et al. 2018). The inhibitory activities of Streptomyces from
Tetragonula laeviceps and Tetragonula fuscobalteata nests were reported to inhibit the causing agent of American foulbrood disease, Paenibacillus larvae, and European foulbrood disease, Melisococcus plutonius (Kroiss et al. 2010). Moreover, bacterial species associated with stingless bees were found to produce antimicrobial compounds (Ngalimat et al. 2019; Paludo et al. 2016) as well as enzymes including lipase and protease (Gilliam et al. 1990; Ngalimat et al. 2019). The bacteria were also investigated for their probiotic potential (Amin et al. 2020).

The aim of this review was to discuss the association of bacteria with stingless bees succinctly. Here, we summarized the common bacterial genera that are associated with stingless bees. The contribution to the formation and enhancement of antimicrobial activities of bee products are described. The potential applications of the bacteria associated with bees as a potential biocontrol agent as well as a producer of antimicrobial compounds and enzymes were also highlighted.

\section{BACTERIA LIVING IN STINGLESS BEE COLONIES}

The information on the association of bacteria with stingless bees is available only for a few stingless bee genera, namely Austroplebeia, Heterotrigona, Melipona, Proplebeia, Scaptotrigona, Tetragonisca, Tetragonula, and Trigona (Table 1). There are three major groups of bacteria associated with stingless bees, namely Bacillus spp., Streptomyces spp. and lactic acid bacteria (LAB). Apart from these three groups, other genera are highlighted in the section below.

TABLE 1. Bacteria associated with varieties of stingless bee species

\begin{tabular}{|c|c|c|c|}
\hline Isolated species & Bee species or bee substrate for bacterial isolation & Locality & Reference \\
\hline \multirow[t]{7}{*}{ Bacillus spp. } & Hetetrigona itama honey & Malaysia & (Amin et al. 2020) \\
\hline & Hetetrigona itama honey, bee bread and propolis & Malaysia & (Ngalimat et al. 2019) \\
\hline & Larval gut of Scaptotrigona depilis & Brazil & (Paludo et al. 2016) \\
\hline & Tetragonisca angustula honey & Argentina & (Pucciarelli et al. 2014) \\
\hline & $\begin{array}{c}\text { Abdominal contents of Proplebeia dorninicana } \\
\text { preserved for } 25 \text { to } 40 \text { million years in buried } \\
\text { Dominican amber }\end{array}$ & Dominican Republic & (Cano \& Borucki 1995) \\
\hline & $\begin{array}{l}\text { Pollen, honey and brood provisions of Malipona } \\
\text { fasciata }\end{array}$ & Panama City & (Gilliam et al. 1990) \\
\hline & Larval provisions of Trigona hypogea & Panama City & (Gilliam et al. 1985) \\
\hline Clostridium spp. & Tetragonisca angustula honey & Argentina & (Pucciarelli et al. 2014) \\
\hline Enterococcus spp. & Tetragonisca angustula honey & Argentina & (Pucciarelli et al. 2014) \\
\hline Enterobacter spp. & Hetetrigona itama propolis & Malaysia & (Ngalimat et al. 2019) \\
\hline $\begin{array}{l}\text { Fructobacillus } \\
\text { spp. }\end{array}$ & Fresh Hetetrigona itama honey & Malaysia & (Yaacob et al. 2018) \\
\hline
\end{tabular}


Lactobacillus spp.

Lysinibacillus $\mathrm{sp}$

Paenibacillus sp.

Pantoea sp.

Staphylococcus

spp.

Streptomyces spp.

Uncultured Streptococcus sp.

Uncultured Acetobacteraceae $\mathrm{sp}$.
Fresh Hetetrigona itama honey

Abdomens of Melipona quadrifasciata

Austroplebeia australis, Tetragonula carbonaria and Tetragonula hockingsii

The nest of Tetragonula carbonaria

Larval food of Melipona scutellaris

Hetetrigona itama propolis

Tetragonisca angustula honey

Hetetrigona itama bee bread

Brood cells and nest materials of Tetragonula laeviceps and Tetragonula fuscobalteata

Abdomens of Melipona quadrifasciata

Abdomens of Melipona quadrifasciata
Malaysia

Brazil

Australia

Australia

Brazil

Malaysia

Argentina

Malaysia

Thailand

Brazil

Brazil
(Yaacob et al. 2018)

(Díaz et al. 2016)

(Leonhardt \& Kaltenpoth 2014)

(Shanks et al. 2017)

(Menegatti et al. 2018)

(Ngalimat et al. 2019)

(Pucciarelli et al. 2014)

(Ngalimat et al. 2019)

(Promnuan et al. 2009)

(Díaz et al. 2016)

(Díaz et al. 2016)

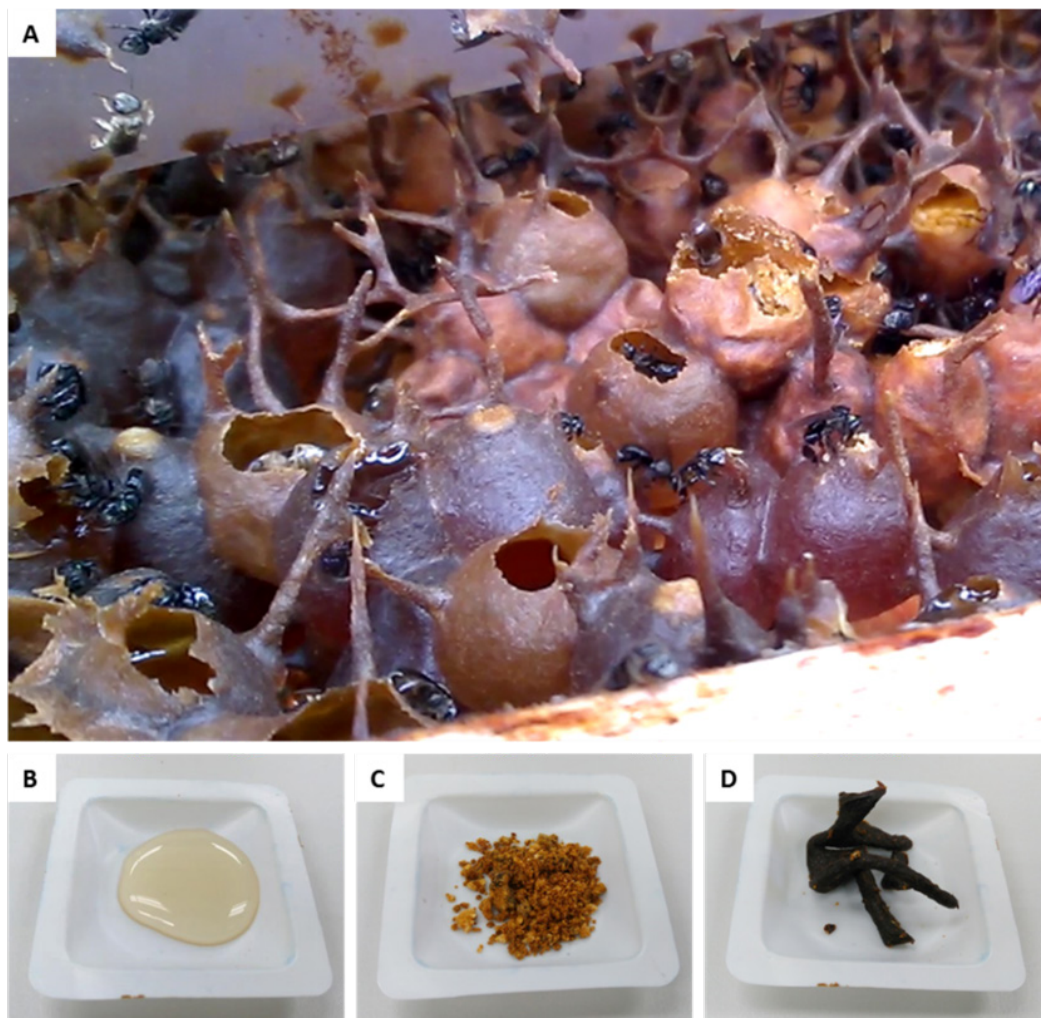

FIGURE 1. The stingless bee, Heterotrigona itama nest products. (A) The stingless bee products in the nest; (B) Honey; (C) Bee bread and (D) Propolis 
Bacillus spp.

Spore-forming bacteria from the genus Bacillus are commonly associated with stingless bee species (Gilliam et al. 1990; 1985; Ngalimat et al. 2019; Pucciarelli et al. 2014). The DNA evidence of this bacterial genus has been found in the abdominal contents of the extinct Proplebeia dorninicana, which was preserved for 25 to 40 million years in the Dominican amber (Cano \& Borucki 1995). Therefore, this evidence is proof of an ancient interaction between stingless bees and Bacillus due to the robustness of the bacterial endospore that is resistant to heat, radiation, and chemicals (Nicholson 2002; Setlow 2014). Some Bacillus associated with stingless bee nests were obtained from Melipona panamica (B. alvei, $B$. circulans and B. megaterium) and Trigona necrophaga ( $B$. circulans, B. licheniformis, B. megaterium, B. pumilus, and B. subtilis) nests in Panama (Gilliam et al. 1990). Apart from that, B. meliponotrophicus was suggested to have a close relationship with the stingless bees because it can be found in the intestines and the storage pots of Melipona quadrifasciata (Cruz-Landim \& Serrão 1996). Machado (1971) has suggested that B. meliponotrophicus associated with stingless bees, such as Trigona and Melipona, could be involved in the fermentation of honey and bee bread. The application of antibiotic namely streptomycin to kill the bacterium resulted in the collapse of the stingless bee colony (Machado 1971; Morais et al. 2013; Quezada-Euán 2018).

\section{Streptomyces spp.}

Streptomyces spp. are Gram-positive and spore-forming bacteria that are widely distributed in soil and aquatic environments, such as rivers, lakes and other freshwater habitats (Goodfellow et al. 1986). Streptomycetes spp. have been found in pollen, provisions and alimentary canals of alfalfa leafcutter bee, Megachile rotundata (Inglis et al. 1993) and in the nest materials of honeybees (including Apis florea, Apis cerana and Apis mellifera) (Promnuan et al. 2009). This bacterial genus was considered as a part of the resident microflora of the bee (Inglis et al. 1993). Evidently, Streptomyces was found associated with the brood cells and hive materials of stingless bees (including Tetragonula laeviceps and Tetragonula fuscobalteata) from the northern region of Thailand. Among the species of Streptomyces found were $S$. albus, $S$. ambofaciens, $S$. coalescens, $S$. drozdowiczii, S. malaysiensis, S. minutiscleroticus, $S$. mutabilis, S. pseudogriseolus, S. rochei, S. tosaensis, and S. violaceoruber (Promnuan et al. 2009). Besides, being a part of the resident microflora, Streptomyces species associated with European beewolf was found to secrete antibiotics, such as piericidines and streptochlorin, onto the brood cells (Kroiss et al. 2010). Interestingly, the antibiotic compounds were found in much higher concentrations on the outer surface than on the inner surface of the cocoon. The antibiotics were suggested to protect the larval cocoon from a diverse range of potentially pathogenic microbes. Similar functions could also be observed in stingless bees' Streptomyces (Promnuan et al. 2009).

\section{LACTIC ACID BACTERIA}

Lactic acid bacteria (LAB) from the genera Lactobacillus and Bifidobacterium are found in bee colonies. They were isolated from several bee species, including honeybees, bumblebees, and stingless bees (Audisio et al. 2011; Tajabadi et al. 2013; Vásquez \& Olofsson 2009; Vásquez et al. 2012; Yaacob et al. 2018). In the Melipona quadrifasciata colony, the preseznce of Lactobacillus was observed through metabarcoding analysis (Díaz et al. 2016). Lactobacillus and Fructobacillus were also isolated from the honey of Malaysian stingless bees, Heterotrigona itama (Yaacob et al. 2018). LAB from the genera Lactobacillus and Bifidobacterium have also been isolated from the honey crop of Melipona beecheii, Meliponula bocandei and Trigona sp. colonies (Vásquez et al. 2012). In the honeybee (Apis mellifera) colony, LAB were suggested to have played a role in the bee bread formation through lactic acid fermentation (Vásquez \& Olofsson 2009). In the stingless bee colonies, the widespread occurrence of LAB has been reported (Lani et al. 2017; Leonhardt \& Kaltenpoth 2014). LAB have major roles in the protection against pathogens (Forsgren et al. 2010; Vásquez et al., 2012) as well as in the pollen fermentation in the nests (Vasquez \& Olofsson 2009).

\section{OTHER GENERA}

Other bacterial genera found were enteric bacteria including Staphylococcus, Escherichia, Enterococcus, and Salmonella, which were isolated from Tetragonisca angustula honey (Pucciarelli et al. 2014). Ralstonia and Pantoea were isolated from Australian stingless bee species, namely Austroplebeia australis, Tetragonula carbonaria, and Tetragonula hockingsii (Leonhardt \& Kaltenpoth 2014). Gram-negative bacteria belonging to the family of Enterobacteriaceae and Acetobacteraceae have also been isolated from the nest of stingless bees from the genera Melipona and Tetragonula (Díaz et al. 2016; Leonhardt \& Kaltenpoth 2014). Since the native habitat of enteric bacteria is the enteric tract of animals, their presence generally indicates direct or indirect contamination of fecal origin (Sanz et al. 1995). Moreover, Clostridium spp. were also found in Tetragonisca angustula honey (Pucciarelli et al. 2014). This spore-forming bacterium has been considered as a primary contaminant (Snowdon \& Cliver 1996) and the detection of this species in honey is vital to determine its quality (Pucciarelli et al. 2014).

A brood disease-causing bacterium, Lysinibacillus sphaericus was isolated from worker and queen larvae, brood cell provisions and honey stores of Tetragonula carbonaria (Shanks et al. 2017). Lysinibacillus sphaericus 
causes Shanks brood disease where recorded a range of symptoms in larvae, brood, hive structures and bee behavior. Moreover, the isolation of Paenibacillus polymyxa ALLI03-01 from the larval food of Melipona scutellaris has also been reported (Menegatti et al. 2018). Paenibacillus polymyxa usually found in various environments; including the plant rhizosphere and marine sediments. This bacterium has been used in agriculture as a biofertilizer and a biocontrol agent (Grady et al. 2016). It was also suggested that this bacterium protected the $M$. scutellaris colony by producing (L)-(-)-3-phenyllactic acid and fusaricidins, which are active against entomopathogenic fungi and Paenibacillus larvae (Menegatti et al. 2018).

\section{CONTRIBUTION OF BACTERIA TO THE BEE PRODUCT FORMATIONS}

To date, the contribution of bacteria on the bee nest is poorly understood. The bacteria have been hypothesized to contribute to the formation of bee products (Klepzig et al. 2009). They were suggested to contribute to the conversion of nectar and pollen into honey and bee bread separately by their enzymatic reactions. In addition, the bacteria potentially contributed to the protection of nests (Roubik 2006). They produced antimicrobial compounds to inhibit the proliferation of pathogenic and spoilage microorganisms (Yoshiyama \& Kimura 2009).

\section{METABOLIC CONVERSION OF NECTAR INTO HONEY}

Honey is the main source of carbohydrates for bees (Haydak 1970). It is a natural, sweet substance generated from plant nectar, living plant secretions or plant-sucking insect excretions. This substance is collected, transformed and combined with the secretion obtained from the bees' salivary glands, which is then stored in the storage pot to mature (Krell 1996). Stingless bees produce honey, which has a strong acid flavor, a less viscous and a darker color in comparison to the honey of honeybees (Garedew et al. 2003). The honey of stingless bees has been widely used because of its therapeutic effects (Amin et al. 2018; Sgariglia et al. 2010). It contains more than 200 substances including carbohydrates, amino acids, proteins, vitamins, minerals, organic acids, flavonoids, and hydroxymethylfurfural (Roowi et al. 2016). Different stingless bee species produce different compositions of honey with distinct organoleptic properties. For instance, Tetragonisca angustula honey appeared to be particularly rich in oligosaccharides (16.0\%) compared to Plebeia wittmanni honey (7.5\%) (Sgariglia et al. 2010). However, the honey composition depends on the bee species and the plants on which the bee feeds on (Barth et al. 2013).

The mechanism of honey formation is not well described. It might be related to the metabolic transformation of nectar into honey by the microflora of bees in both the bee gut and the storage pot (Anderson et al. 2011). In the formation of honey, the collected nectar undergoes three types of changes: Physical; dehydration process; chemical; enzymatic reaction; and biological; microbial fermentation (Menezes et al. 2013). In the dehydration process, the water content of the nectar begins to reduce through evaporation as bees fly to their nest (Human \& Nicolson 2006). Within the nest, the water content of nectar will be further reduced through regurgitation and evaporation (Vásquez \& Olofsson 2009).

Inside the nest, nectar is biochemically converted into honey. The conversion of nectar into honey is complex because it involves many types of enzymes (including $\alpha$-amylase, $\beta$-glucosidase and glucose oxidase) that need for the honey formation (White \& Maher 1953). Evidently, the hypopharyngeal gland of Scaptotrigona postica (Costa \& Cruz-landim 2005) and bacteria from Melipona fasciata nest (Gilliam et al. 1990) were found to be rich in the glycolytic enzymes. Enzymes originated from bees and microbes were hypothesized to contribute to the conversion of nectar into honey. In honeybee colonies, research has shown that the oligosaccharides found in the honey samples originated from the $\alpha$ - and $\beta$-glucosidase activities (Low et al. 1988). Moreover, the biochemical reaction of nectar into honey has also been catalyzed by the glucose oxidase. This enzyme produced by bees and microbes catalyzed the conversion of glucose into gluconic acid (Gilliam 1997). It is worth noting that gluconic acid is the main acid that can be found in honey (Burgett 1974).

Honey fermentation occurs inside the storage pots (Souza et al. 2007). Inside the storage pots, the transformation of sugar molecules into alcohol and carbon dioxide occur through alcoholic fermentation. This type of fermentation is mostly performed by yeasts (Rosa et al. 2003; Teixeira et al. 2003) and bacteria (Gilliam et al. 1990). Lactic fermentation generated by LAB causes the conversion of sugar into lactic acid and water (Audisio et al. 2011). LAB contribute to the formation of honey from nectar, and beebread from pollen, due to their fermentation activities (Olofsson \& Vásquez 2008; Vásquez et al. 2012). Olofsson et al. (2016) has also hypothesized that the LAB produced bioactive metabolites that become part of the ripen honey. In the honeybee's colony, fructophilic LAB have been found strongly associated with the gastrointestinal tracts of Apis mellifera L. worker bees (Filannino et al. 2016). Fructophilic LAB utilized varieties of phenolic acids, such as $\rho$-coumaric, caffeic, syringic and gallic acids; suggesting that these bacteria are involved in the fermentation process of nectar and pollen.

\section{METABOLIC CONVERSION OF POLLEN INTO BEE BREAD}

Bee bread is generated using pollen grains as raw material that bees collect from various plant anthers (Herbert \& Shimanuki 1978). Pollen grains are collected and transported by foraging bees on their hind legs in a specialized pollen basket (Michener 1974). Within the nest, pollen grains are mixed with the secretion from the 
bees' salivary glands or nectar before being preserved and further fermented in the storage pot (DeGrandi-Hoffman et al. 2013; Komosinska-Vassev et al. 2015). After two weeks, chemically changes apparently occurs due to the natural fermentation caused by the intervention of different microorganisms (Menezes et al. 2013). Lactic acid fermentation activities by bacteria from the genera Streptococcus, Bifidobacterium, and Lactobacillus were suggested to be involved in the biochemical conversion of pollen grains into bee bread (Vásquez \& Olofsson 2009). In addition, Bacillus species in Melipona panamica nests were shown to secrete enzymes that catalyze the breakdown of lipids, carbohydrates and proteins. This bacterial genus was found predominant in pollen and some species are known to ferment glucose. Therefore, this suggests that Bacillus species is an important genus that could be involved in the bee bread formation (Gilliam et al. 1990, 1985).

As the fermentation process comes to completion, a high content of lactic acid preserves the bee bread from spoilage by microorganisms. The chemical composition of bee bread, such as flavor, color, and texture changes considerably after being stored and these characteristics vary among bee species. For examples, the bee bread of stingless bee from the genera Frieseomelitta and Tetragonisca are dry and sweet while the ones produced by Melipona and Scaptotrigona are moist and sour (Souza et al. 2004).

\section{FORMATION OF PROPOLIS}

The term propolis derives from the Greek word which is a 'pro' (at the entrance to) and 'polis' (city). Propolis is also known as the 'bee glue' which is a sticky dark coloured material that bees collected from various living plants such as from the tree buds and sap flows of numerous tree species. Propolis is composed of resin and wax, balsam, essential and aromatic oils, pollen and various other substances including organic debris (Burdock 1998). Chemical compositions of propolis are complex which include flavones, flavanones, and phenolic acids and their esters (Bankova 2005).

In literature, theory for the propolis formation has been proposed (Küstenmacher 1911). Propolis is manufactured by using substances that obtained from material secreted and exuded by plants. It is then mixed with the bee's saliva and beeswax which then gives rise to propolis (Kadhim et al. 2018). Due to its waxy nature and mechanical properties, bees use propolis in the construction and repair of their hives (Wagh 2013). In fact, it is the most important building block to act against the proliferation of spoilage and pathogenic microbes (Bankova 2005).

The contribution of bacteria to the propolis formation is still unclear. Many studies reported on a plethora of biological activities of propolis including antibacterial (Choudhari et al. 2012; Georgieva et al. 2019; Lavinas et al. 2019), antifungal (Campos et al. 2015; Shehu et al. 2016), and antiviral (Coelho et al. 2014; 2018) activities. Moreover, studies also reported on the isolation of yeasts (Rosa et al. 2003; Teixeira et al. 2003) and bacteria (Ngalimat et al. 2019) from propolis, but not on the bacterial functionality to the propolis formation. Thus, this make the biological role of bacteria on propolis remains elusive.

\section{ENHANCEMENT OF ANTIMICROBIAL ACTIVITIES OF BEE} PRODUCTS

Bee products generated from plant-based materials are rich in macromolecules and possess plenty of antimicrobial activities (Amin et al. 2018). Stingless bee products, such as honey are rich in antimicrobial activities due to its high sugar concentration, acidity, hydrogen peroxide and phytochemical compounds (Sinacori et al. 2014). Bacteria were hypothesized to contribute to the antimicrobial properties of bee products (Reynaldi et al. 2004). The bacterial antimicrobial compounds, such as polymyxins, octapeptins, polypeptins, iturins, fengycins, and surfactins were possibly used to prevent the proliferation of pathogenic and spoilage microorganisms (Cochrane \& Vederas 2014; Gilliam 1997).

In the honeybee colony, bacteria from the bee larvae, namely Stenotrophomonas maltophilia, Acinetobacter sp., Brevibacillus formosus and Bacillus fusiformis were found to inhibit $P$. larvae subsp. larvae; a Grampositive bacterium, which was the causative agent of the widespread larval disease American foulbrood (Evans \& Armstrong 2005; Graaf et al. 2006). Furthermore, Bacillus cereus and Bacillus subtilis from the digestive tract of Japanese honeybees were also found to inhibit P. larvae (Yoshiyama \& Kimura 2009). The production of surfactin by $B$. subtilis was reported to inhibit the honeybee pathogens including $P$. larvae, Ascosphaera apis and Nosema ceranae (Porrini et al. 2010). In addition, the presence of secondary metabolites pathways, such as streptomycin and xenobiotic biodegradation genes in the bee bread using metatranscriptomic analysis supported the hypothesis on the possible roles of microflora in maintaining the sustainability of bee nests against pathogenic and spoilage microbes (Saraiva et al. 2015).

Streptomyces spp., namely $S$. drozdowiczii, S. albus and $S$. malaysiensis interact symbiotically with bees by secreting antibiotics, such as streptochlorin, piericidins, and glucopiericidin (Kroiss et al. 2010; Promnuan et al. 2009). This bacterial genus was found to have a unique association with the European beewolf, Philanthus triangulum. The female beewolf transferred Streptomyces inside their antennal glands to the brood cell. The bacteria then spread inside brood cells and secrete antibiotic substances that protect the larvae from fungi and other pathogens. Bioassays have also indicated that the bacteria protected the cocoon from fungal infestation, thus, enhancing the survivability of the larvae (Kroiss et al. 2010). 
POTENTIAL APPLICATION OF BACTERIA ASSOCIATED WITH BEES

The subject of this section has been extensively explored in honeybees, from which bacteria have been reported as biological control agents, as well as antimicrobial compounds and hydrolytic enzymes producers (Butler et al. 2013; Disayathanoowat et al. 2012; Evans \& Armstrong 2005). However, only a few studies consider the potential applications of bacteria isolated from stingless bees (Amin et al. 2020; Ngalimat et al. 2019).

Bacteria isolated from honey samples have shown antimicrobial activities against pathogenic bacteria. The bacteria from the genera Stenotrophomonas, Acinetobacter, Brevibacillus and Bacillus isolated from the honey of honeybees were found to inhibit the causative agent of American foulbrood disease (Evans \& Armstrong 2005). The causal agent of chalkbrood disease was inhibited by bacteria from the genus Bacillus ( $B$. megaterium, $B$. licheniformis and $B$. cereus) isolated from apiarian sources (Alippi \& Reynaldi 2006). A noteworthy bacterial species with potential as a biological control agent named $B$. amyloliquefaciens is commonly isolated from both honeybees (Wang et al. 2015; Zhao et al. 2013) and stingless bees (Ngalimat et al. 2019; Paludo et al. 2016) colonies. Bacillus amyloliquefaciens strains were reported as the biological control agent to inhibit many plant pathogens including Botrytis cinerea (Mari et al. 1996), Colletotrichum lagenarium (Kim \& Chung 2004), Fusarium oxysporum (Yuan et al. 2012; Zhao et al. 2014), Penicillium expansum (Arrebola et al. 2010), Sclerotinia sclerotiorum (Abdullah et al. 2008), Sphaerotheca fuliginea (Li et al. 2015), Ralstonia solanacearum (Singh et al. 2016a) and Xanthomonas oryzae (Wu et al. 2015). Noteworthy, Bacillus species from stingless bee honey have also been evaluated for their probiotic properties. Bacillus amyloliquefaciens HTI-19 and B. subtilis HTI-23 isolated from Heterotrigona itama honey showed good probiotic properties (Amin et al. 2020).

Besides their potential as a biological control agent and probiotic strains, bacteria are also a good source of antimicrobial compounds. Antimicrobial peptides, such as fengycin, macrolactin, bacilysin, bacillibactin and difficidin were found from Bacillus sp. SDLI1 isolated from Scaptotrigona depilis larvae (Paludo et al. 2016). Antifungal peptide genes including ituA (iturin A) and hag (flagellin) were identified from Bacillus sp. BH072, which was isolated from the honeybee honey. In addition, B. amyloliquefaciens, a common stingless bee associated with bacteria, produced antimicrobial peptides, such as surfactin (Arguelles-Arias et al. 2009; Harwood et al. 2018). Bacillus amyloliquefaciens surfactin was reported to act against antibiotic-resistant Staphylococcus aureus and Escherichia coli strains as well as pathogenic yeast, Candida albicans (Ndlovu et al. 2017). Moreover, Enterococcus faecium SM21 from the gut of honeybees produced bacteriocin-like compounds with anti-Listeria effects (Audisio et al. 2011). The LAB from the genera Lactobacillus and Bifidobacterium isolated from the honeybee honey were reported to produce bacteriocins (Butler et al. 2013).

Enzymes found in nature have been used in textile applications, the feed manufacturing industry, the processing of fats and oils, the food industry and organic synthesis (Kirk et al. 2002). Microbial enzymes have attracted interest because of their widespread use in industries, owing to their stability and catalytic activity under abnormal temperature and $\mathrm{pH}$ conditions (Singh et al. 2016b). Bacteria from the bee products could be the source of industrial enzymes. Bacteria from the midgut of honeybees, namely Klebsiella oxytoca, Enterobacter cloacae, Enterobacter gergoviae, and Pantoea dispersa has shown proteolytic activity whereas that of Klebsiella pneumoniae, Citrobacter freundii, Enterobacter aerogenes, Enterobacter cloacae exhibited lipolytic activity (Disayathanoowat et al. 2012). Pectate lyase, an enzyme used in food production and textile industries was produced by Gilliamella that was isolated from the gut of honeybees (Engel et al. 2012). Proteolytic, lipolytic, and cellulolytic activities were also detected from bacterial species isolated from Heterotigona itama honey, bee bread, and propolis (Ngalimat et al. 2019). Furthermore, B. amyloliquefaciens isolated from the guts of honeybees was found to produce $\alpha$-amylase (Wang et al. 2015). To note, these bacterial strains have been reported to produce various type of extracellular hydrolytic enzymes including lipase (Saengsanga et al. 2016), protease (Wang et al. 2016), laccase (Lončar et al. 2014), cellulase (Ye et al. 2017) and xylanase (Amore et al. 2015).

\section{CONCLUSIONS AND FUTURE PROSPECTS}

In this review, we have described the bacteria that are commonly found in stingless bee products as well as their association. The bacteria are not only essential to convert the raw materials such as nectar and pollen into honey and bee bread, respectively, but also crucial in protecting the bee nest from food spoilage microorganisms. These activities are due to the action of the enzymes and antimicrobial compounds produced by the bacteria. As it is suggested that the formation of bee products is a result of the metabolic activity of the bee's microflora, the biological roles of bee's microflora are presently open to speculation. As most of the bacteria found are spore-forming bacteria, one question remains: do the bacteria are active while present in bee products or remain dormant (as spores)? The functionality of the bacteria associated with stingless bees has yet to be explored. Therefore, it is necessary to conduct further studies to determine in vivo metabolic activities and the physiological characteristics of the bacterial species associated with stingless bees. Understanding such attributes will help to shed light on the functionality as well as the biological roles of the bacteria to the stingless 
bee products formation. Also, it is now clearly established that some of the bacterial species associated with bees are effective against human and plant pathogens. The bacteria are not only used as biocontrol agents and as antimicrobial compound producers, but also as a source of important enzymes. These show that bee products can be a good source of beneficial bacteria with a wide range of possible industrial applications. On the other note, understanding the relationship between stingless bees and microbes has become one of the approaches to guarantee the sustainability of the meliponiculture. The studies of the microbial diversity in healthy stingless bee's colonies should be conducted as it may provide valuable knowledge on the importance of bee's microflora to the stingless bee's health and productivity.

\section{ACKNOWLEDGEMENTS}

This research is supported by Universiti Putra MalaysiaPutra Graduate Initiative (GP-IPS/2018/9601400). Mohamad Syazwan Ngalimat is supported by GRF scholarship from Universiti Putra Malaysia.

\section{REFERENCES}

Abdullah, M.T., Ali, N.Y. \& Suleman, P. 2008. Biological control of Sclerotinia sclerotiorum (Lib.) de Bary with Trichoderma harzianum and Bacillus amyloliquefaciens. Crop Protection 27(10): 1354-1359.

Alippi, A.M. \& Reynaldi, F.J. 2006. Inhibition of the growth of Paenibacillus larvae, the causal agent of American Foulbrood of honeybees, by selected strains of aerobic sporeforming bacteria isolated from apiarian sources. Journal of Invertebrate Pathology 91(3): 141-146.

Amin, F.A.Z., Sabri, S., Ismail, M., Chan, K.W., Ismail, N., Mohd Esa, N., Mohd Lila, M.A. \& Zawawi, N. 2020. Probiotic properties of Bacillus strains isolated from stingless bee (Heterotrigona itama) honey collected across Malaysia. International Journal of Environmental Research and Public Health 17(1): 278.

Amin, F.A.Z., Sabri, S., Mohammad, S.M., Ismail, M., Chan, K.W., Ismail, N., Mohd, E.N. \& Zawawi, N. 2018. Therapeutic properties of stingless bee honey in comparison with European bee honey. Advances in Pharmacological Sciences 2018: Article ID. 6179596.

Amore, A., Parameswaran, B., Kumar, R., Birolo, L., Vinciguerra, R., Marcolongo, L., Ionata, E., La Cara, F., Pandey, A. \& Faraco, V. 2015. Application of a new xylanase activity from Bacillus amyloliquefaciens XR44A in brewer's spent grain saccharification. Journal of Chemical Technology and Biotechnology 90(3): 573-581.

Anderson, K.E., Sheehan, T.H., Eckholm, B.J., Mott, B.M. \& DeGarndi-Hoffman, G. 2011. An emerging paradigm of colony health: Microbial balance of the honey bee and hive (Apis mellifera). Insectes Sociaux 58: 431-444.

Arguelles-Arias, A., Ongena, M., Halimi, B., Lara, Y., Brans, A., Joris, B. \& Fickers, P. 2009. Bacillus amyloliquefaciens GA1 as a source of potent antibiotics and other secondary metabolites for biocontrol of plant pathogens. Microbial Cell Factories 8(1): 63.

Arrebola, E., Jacobs, R. \& Korsten, L. 2010. Iturin A is the principal inhibitor in the biocontrol activity of Bacillus amyloliquefaciens PPCB004 against postharvest fungal pathogens. Journal of Applied Microbiology 108(2): 386-395.

Audisio, M.C., Torres, J.M., Sabate, D.C., Ibarguren, C. \& Apella, M.C. 2011. Properties of different lactic acid bacteria isolated from Apis mellifera L. bee-gut. Microbiological Research 166: 1-13.

Bankova, V. 2005. Recent trends and important developments in propolis research. Evidence-Based Complementary and Alternative Medicine 2(1): 29-32.

Barth, O.M., Freitas, A.S., Sousa, G.L. \& Almeida-Muradian, L.B. 2013. Pollen and physicochemical analysis of Apis and Tetragonisca (Apidae) honey. Interciencia 38(4): 280-285.

Bassindale, R. \& Matthews, L.H. 1955. The biology of the stingless bee Trigonu (Hypotrigona) gribodoi magretti (meliponidae). Proceedings of the Zoological Society of London 125: 49-62.

Burdock, G.A. 1998. Review of the biological properties and toxicity of bee propolis (propolis). Food and Chemical Toxicology 36(4): 347-363.

Burgett, D.M. 1974. Glucose oxidase: A food protective mechanism in social hymenoptera. Annals of the Entomological Society of America 67(4): 545-546.

Butler, È., Alsterfjord, M., Olofsson, T.C., Karlsson, C., Malmström, J. \& Vásquez, A. 2013. Proteins of novel lactic acid bacteria from Apis mellifera mellifera: An insight into the production of known extra-cellular proteins during microbial stress. BMC Microbiology 13: 235.

Campos, J.F., Santos, U.P.D., Rocha, P.D.S.D., Damião, M.J., Balestieri, J.B.P., Cardoso, C.A.L., Paredes-Gamero, E.J., Estevinho, L.M., de Picoli Souza, K. \& Santos, E.L.D. 2015. Antimicrobial, antioxidant, anti-inflammatory, and cytotoxic activities of propolis from the stingless bee Tetragonisca fiebrigi (Jataí). Evidence-Based Complementary and Alternative Medicine 2015: Article ID. 296186.

Cano, R.J. \& Borucki, M.K. 1995. Revival and identification of bacterial spores in 25- to 40-million-year-old dominican amber. Science 268(5213): 1060-1064.

Choudhari, M.K., Punekar, S.A., Ranade, R.V. \& Paknikar, K.M. 2012. Antimicrobial activity of stingless bee (Trigona sp.) propolis used in the folk medicine of Western Maharashtra, India. Journal of Ethnopharmacology 141(1): 363-367.

Cochrane, S.A. \& Vederas, J.C. 2014. Lipopeptides from Bacillus and Paenibacillus spp.: A gold mine of antibiotic candidates. Medicinal Research Reviews 36(1): 4-31.

Coelho, G.R., Figueiredo, C.A., Negri, G., Fernandes-Silva, C.C., Villar, K.D.S., Badari, J.C., de Oliveira, M.I., Barbosa, T.F., Taniwaki, N.N., Namiyama, G.M. \& Mendonça, R.Z. 2018. Antiviral activity of geopropolis extract from Scaptotrigona aff. postica against rubella virus. Journal of Food Research 7(6): 91-106.

Coelho, G.R., de Senna Villar, K., Figueiredo, C.A., Badari, J.C., Mendonça, R.M.Z., Oliveira, M.I., Curti, S.P., Silva, P.E.S., Do Nascimento, R.M. \& Mendonça, R.Z. 2014. Antiviral effects of Scaptotrigona postica propolis and their fractions. BMC Proceedings 8(Suppl 4): P63.

Costa, R.A.C. \& Cruz-Landim, C. 2005. Hydrolases in the hypopharyngeal glands of workers of Scaptotrigona postica and Apis mellifera (Hymenoptera, Apinae). Genetics and Molecular Research 4(4): 616-623.

Cruz-Landim, D. \& Serrão, J.E. 1996. Ultrastructure and histochemistry of the mineral concretions in the midgut of bees (Hymenoptera: Apidae) ${ }^{1}$. Netherlands Journal of Zoology 47(1): 21-29. 
DeGrandi-Hoffman, G., Eckholm, B.J. \& Huang, M.H. 2013. A comparison of bee bread made by Africanized and European honey bees (Apis Mellifera) and its effects on hemolymph protein titers. Apidologie 44: 52-63.

Díaz, S., Urbano, S.D.S., Caesar, L., Blochtein, B., Sattler, A., Zuge, V. \& Haag, K.L. 2016. Report on the microbiota of Melipona quadrifasciata affected by a recurrent disease. Journal of Invertebrate Pathology 143: 35-39.

Disayathanoowat, T., Yoshiyama, M., Kimura, K. \& Chantawannakul, P. 2012. Isolation and characterization of bacteria from the midgut of the asian honey bee (Apis cerana indica). Journal of Apicultural Research 51(4): 312-319.

Engel, P., Martinson, V.G. \& Moran, N.A. 2012. Functional diversity within the simple gut microbiota of the honey bee. Proceedings of the National Academy of Sciences of the United States of America 109(27): 11002-11007.

Evans, J.D. \& Armstrong, T. 2005. Inhibition of the American foulbrood bacterium, Paenibacillus larvae larvae, by bacteria isolated from honey bees. Journal of Apicultural Research 44(4): 168-171.

Filannino, P., Di Cagno, R., Addante, R., Pontonio, E. \& Gobbetti, M. 2016. Metabolism of fructophilic lactic acid bacteria isolated from the Apis mellifera L. bee gut: Phenolic acids as external electron acceptors. Applied and Environmental Microbiology 82(23): 6899-6911.

Forsgren, E., Olofsson, T.C., Vasquez, A. \& Fries, I. 2010. Novel lactic acid bacteria inhibiting Paenibacillus larvae in honeybee larvae. Apidologie 41: 99-108.

Garedew, A., Schmolz, E. \& Lamprecht, I. 2003. The antimicrobial activity of honey of the stingless bee Trigona spp. Journal of Apicultural Science 47(1): 37-49.

Georgieva, K., Popova, M., Dimitrova, L., Trusheva, B., Phuong, D.T.L., Lien, N.T.P., Najdenski, H. \& Bankova, V. 2019. Phytochemical analysis of Vietnamese propolis produced by the stingless bee Lisotrigona cacciae. PLoS ONE 14(4): e0216074

Gilliam, M. 1997. Identification and roles of non-pathogenic microflora associated with honey bees. FEMS Microbiology Letters 155: 1-10.

Gilliam, M., Roubik, D.W. \& Lorenz, B.J. 1990. Microorganisms associated with pollen, honey, and brood provisions in the nest of a stingless bee, Melipona fasciata. Apidologie 21(2): 89-97.

Gilliam, M., Buchmann, S.L., Lorenz, B.J. \& Roubik, D.W. 1985. Microbiology of the larval provisions of the stingless bee, Trigona hypogea, an obligate necrophage. Biotropica 17(1): 28-31.

Goodfellow, M., Williams, S.T. \& Alderson, G. 1986. Transfer of Chainia species to the genus Streptomyces with emended description of species. Systematic and Applied Microbiology 8(1-2): 55-60

Graaf, D.C.D., Alippi, A.M., Brown, M., Evans, J.D., Feldlaufer, M., Gregorc, A., Hornitzky, M., Pernal, S.F., Schuch, D.M.T., Titěra, D. \& Tomkies, V. 2006. Diagnosis of American foulbrood in honey bees: A synthesis and proposed analytical protocols. Letters in Applied Microbiology 43(6): 583-590.

Grady, E.N., MacDonald, J., Liu, L., Richman, A. \& Yuan, Z.C. 2016. Current knowledge and perspectives of Paenibacillus: A review. Microbial Cell Factories 15(1): 203.

Harwood, C.R., Mouillon, J.M., Pohl, S. \& Arnau, J. 2018. Secondary metabolite production and the safety of industrially important members of the Bacillus subtilis group. FEMS Microbiology Reviews 42(6): 721-738.
Haydak, M.H. 1970. Honey bee nutrition. Annual Review of Entomology 15: 143-156.

Herbert, E.W. \& Shimanuki, H. 1978. Chemical composition and nutrient value of bee-collected and bee-stored pollen. Apidologie 9(1): 33-40.

Human, H. \& Nicolson, S.W. 2006. Nutritional content of fresh, bee-collected and stored pollen of Aloe greatheadii var. davyana (Asphodelaceae). Phytochemistry 67: 1486-1492.

Inglis, G.D, Sigler, L. \& Goette, M.S. 1993. Aerobic microorganisms associated with Alfalfa leafcutter bees (Megachile rotundata). Microbial Ecology 26(2): 125-143.

Jalil, A.H. 2014. Beescape for Meliponines: Conservation of Indo-Malayan Stingless Bees. Singapore: Partridge.

Kadhim, M.J., Łoś, A., Olszewski K. \& Borsuk G. 2018. Propolis in livestock nutrition. Entomology, Ornithology and Herpetology: Current Research 7(1): 1-4.

Kim, P.I. \& Chung, K.C. 2004. Production of an antifungal protein for control of Colletotrichum lagenarium by Bacillus amyloliquefaciens MET0908. FEMS Microbiology Letters 234(1): 177-183.

Kirk, O., Borchert, T.V. \& Fuglsang, C.C. 2002. Industrial enzyme applications. Current Opinion in Biotechnology 13(4): 345-351

Klepzig, K.D., Adams, A.S., Handelsman, J. \& Raffa, K.F. 2009 Symbioses: A key driver of insect physiological processes, ecological interactions, evolutionary diversification, and impacts on humans. Environmental Entomology 38(1): 67-77.

Komosinska-Vassev, K., Olczyk, P., Kazmierczak, J., Mencner, L. \& Olczyk, K. 2015. Bee pollen: Chemical composition and therapeutic application. Evidence-Based Complementary and Alternative Medicine 2015: 1-6.

Krell, R. 1996. Value-added Products from Beekeeping. FAO Agricultural Services Bulletin No. 124. Rome, Italy: Food and Agriculture Organization of the United Nations.

Kroiss, J., Kaltenpoth, M., Schneider, B., Schwinger, M.G., Hertweck, C., Maddula, R.K., Strohm, E. \& Svatos, A. 2010. Symbiotic Streptomycetes provide antibiotic combination prophylaxis for wasp offspring. Nature Chemical Biology 6(4): 261-263.

Küstenmacher, M. 1911. Propolis. Berichte der Deutshen Pharmacologische Gesellschai 21: 65-92.

Lani, M.N., Zainudin, A.H., Razak, S.B.A., Mansor, A. \& Hassan, Z. 2017. Microbiological quality and pH changes of honey produced by stingless bees, Heterotrigona itama and Geniotrigona thoracica stored at ambient temperature. Malaysian Applied Biology 46(3): 89-96.

Lavinas, F.C., Macedo, E.H.B., Sá, G.B., Amaral, A.C.F., Silva, J.R., Azevedo, M.M., Vieira, B.A., Domingos, T.F.S., Vermelho, A.B., Carneiro, C.S. \& Rodrigues, I.A. 2019. Brazilian stingless bee propolis and geopropolis: Promising sources of biologically active compounds. Revista Brasileira de Farmacognosia 29(3): 389-399.

Leonhardt, S.D. \& Kaltenpoth, M. 2014. Microbial communities of three sympatric Australian stingless bee species. PLoS ONE 9(8): e105718.

Li, Y., Gu, Y., Li, J., Xu, M., Wei, Q. \& Wang, Y. 2015. Biocontrol agent Bacillus amyloliquefaciens LJ02 induces systemic resistance against cucurbits powdery mildew. Frontiers in Microbiology 6: 1-15.

Lončar, N., Gligorijević, N., Božić, N. \& Vujčić, Z. 2014. Congo red degrading laccases from Bacillus amyloliquefaciens strains isolated from salt spring in Serbia. International Biodeterioration and Biodegradation 91: 18-23. 
Low, N.H., Nelson, D.L. \& Sporns, P. 1988. Carbohydrate analysis of Western Canadian honeys and their nectar sources to determine the origin of honey oligosaccharides. Journal of Apicultural Research 27(4): 245-251.

Machado, J.O. 1971. Symbiosis among Brazilian social bees (Meliponinae, Apidae) and a species of bacteria. Ciência e Cultura 23: 625-633.

Mari, M., Guizzardi, M., Brunelli, M. \& Folchi, A. 1996. Postharvest biological control of grey mould (Botrytis cinerea pers.: fr.) on fresh-market tomatoes with Bacillus amyloliquefaciens. Crop Protection 15(8): 699-705.

Menegatti, C., Melo, W.G.D.P., Carrão, D.B., De Oliveira, A.R.M., Do Nascimento, F.S., Lopes, N.P. \& Pupo, M.T. 2018. Paenibacillus polymyxa associated with the stingless bee Melipona scutellaris produces antimicrobial compounds against entomopathogens. Journal of Chemical Ecology 44(12): 1158-1169.

Menezes, C., Vollet-Neto, A., Contrera, F.A.F.L., Venturieri, G.C. \& Imperatriz-Fonseca, V.L. 2013. The role of useful microorganisms to stingless bees and stingless beekeeping. In Pot-Honey: A Legacy of Stingless Bees. New York: Springer. pp. 153-171.

Michener, C.D. 2013. The meliponini. In Pot-Honey: A Legacy of Stingless Bees. New York: Springer. pp. 3-17.

Michener, C.D. 1974. The Social Behavior of the Bees: A Comparative Study. England: Harvard University Press.

Morais, P.B., Calaça, P.S.S.T. \& Rosa, C.A. 2013. Microorganisms associated with stingless bees. In Pot-Honey: A Legacy of Stingless Bees. New York: Springer. pp. 173-186.

Ndlovu, T., Rautenbach, M., Khan, S. \& Khan, W. 2017. Variants of lipopeptides and glycolipids produced by Bacillus amyloliquefaciens and Pseudomonas aeruginosa cultured in different carbon substrates. AMB Express 7(1): 109.

Ngalimat, M.S., Raja Abd. Rahman, R.N.Z., Yusof, M.T., Syahir, A. \& Sabri, S. 2019. Characterisation of bacteria isolated from the stingless bee, Heterotrigona itama, honey, bee bread and propolis. Peer J. 7: e7478.

Nicholson, W.L. 2002. Roles of Bacillus endospores in the environment. Cellular and Molecular Life Sciences 59(1): 410-416.

Olaitan, P.B., Adeleke, O.E. \& Iyabo, O.O. 2007. Honey: A reservoir for microorganisms and an inhibitory. African Health Sciences 7(3): 159-165.

Olofsson, T.C., Butler, È., Markowicz, P., Lindholm, C., Larsson, L. \& Vásquez, A. 2016. Lactic acid bacterial symbionts in honeybees - An unknown key to honey's antimicrobial and therapeutic activities. International Wound Journal 13(5): 668-679.

Olofsson, T.C. \& Vásquez, A. 2008. Detection and identification of a novel lactic acid bacterial flora within the honey stomach of the honeybee Apis mellifera. Current Microbiology 57(4): 356-363.

Paludo, C.R., Ruzzini, A.C., Silva-Junior, E.A., Pishchany, G., Currie, C.R., Nascimento, F.S., Kolter, R.G., Clardy, J. \& Pupo, M.T. 2016. Whole-genome sequence of Bacillus sp. SDLI1, isolated from the social bee Scaptotrigona depilis. Genome Announcements 4(2): e0174-16.

Porrini, M.P., Audisio, M.C., Sabaté, D.C., Ibarguren, C., Medici, S.K., Sarlo, E.G., Garrido, P.M. \& Eguaras, M.J. 2010. Effect of bacterial metabolites on microsporidian Nosema ceranae and on its host Apis mellifera. Parasitology Research 107(2): 381-388.
Promnuan, Y., Kudo, T. \& Chantawannakul, P. 2009. Actinomycetes isolated from beehives in Thailand. World Journal of Microbiology and Biotechnology 25(9): 16851689.

Pucciarelli, A.B., Schapovaloff, M.E., Kummritz, S., Señuk, I.A., Brumovsky, L.A. \& Dallagnol, A.M. 2014. Microbiological and physicochemical analysis of Yateí (Tetragonisca angustula) honey for assessing quality standards and commercialization. Revista Argentina de Microbiología 46(4): 325-332.

Quezada-Euán, J.J.G. 2018. Stingless Bees of Mexico: The Biology, Management and Conservation of an Ancient Heritage. Switzerland: Springer, Cham.

Reynaldi, F.J., De Giusti, M.R. \& Alippi, A.M. 2004. Inhibition of the growth of Ascosphaera apis by Bacillus and Paenibacillus strains isolated from honey. Revista Argentina de Microbiologia 36(1): 52-55.

Roowi, S., Jaafar, N.A.I. \& Abdul Mubdi, N.E. 2016. Madu lebah kelulut dan khasiatnya. In Lebah Kelulut Malaysia Biologi dan Penternakan. Kuala Lumpur: Institut Penyelidikan dan Kemajuan Pertanian Malaysia (MARDI). pp. 71-85.

Rosa, C.A., Lachance, M.A., Silva, J.O., Teixeira, A.C.P., Marini, M.M., Antonini, Y. \& Martins, R.P. 2003. Yeast communities associated with stingless bees. FEMS Yeast Research 4(3): 271-275.

Roubik, D.W. 2006. Stingless bee nesting biology. Apidologie 37: 124-143.

Sachs, J.L., Essenberg, C.J. \& Turcotte, M.M. 2011. New paradigms for the evolution of beneficial infections. Trends in Ecology and Evolution 26(4): 202-209.

Saengsanga, T., Siripornadulsil, W. \& Siripornadulsil, S. 2016. Molecular and enzymatic characterization of alkaline lipase from Bacillus amyloliquefaciens E1PA isolated from lipidrich food waste. Enzyme and Microbial Technology 82: 23-33.

Sanz, S., Gradillas, G., Jimeno, F., Perez, C. \& Juan, T. 1995. Fermentation problem in Spanish north-coast honey. Journal of Food Protection 58(5): 515-518.

Saraiva, M.A., Zemolin, A.P.P., Franco, J.L., Boldo, J.T., Stefenon, V.M., Triplett, E.W., De Oliveira Camargo, F.A. \& Roesch, L.F.W. 2015. Relationship between honeybee nutrition and their microbial communities. Antonie van Leeuwenhoek 107: 921-933.

Setlow, P. 2014. Germination of spores of Bacillus species: What we know and do not know. Journal of Bacteriology 196(7): 1297-1305.

Sgariglia, M.A., Vattuone, M.A., Vattuone, M.M.S., Soberón, J.R. \& Sampietro, D.A. 2010. properties of honey from Tetragonisca angustula fiebrigi and Plebeia wittmanni of Argentina. Apidologie 41: 667-675.

Shanks, J.L., Haigh, A.M., Riegler, M. \& Spooner-Hart, R.N. 2017. First confirmed report of a bacterial brood disease in stingless bees. Journal of Invertebrate Pathology 144: 7-10.

Shehu, A., Ismail, S., Rohin, M.A.K., Harun, A., Aziz, A.A. \& Haque, M. 2016. Antifungal properties of Malaysian Tualang honey and stingless bee propolis against Candida albicans and Cryptococcus neoformans. Journal of Applied Pharmaceutical Science 6(2): 44-50.

Sinacori, M., Francesca, N., Alfonzo, A., Cruciata, M., Sannino, C., Settanni, L. \& Moschetti, G. 2014. Cultivable microorganisms associated with honeys of different geographical and botanical origin. Food Microbiology 38(1): 284-294. 
Singh, D., Yadav, D.K., Chaudhary, G., Rana, V.S. \& Sharma, R.K. 2016a. Potential of Bacillus amyloliquefaciens for biocontrol of bacterial wilt of tomato incited by Ralstonia solanacearum. Journal of Plant Pathology and Microbiology 7(1): 1-6.

Singh, R., Kumar, M., Mittal, A. \& Mehta, P.K. 2016b. Microbial enzymes: Industrial progress in 21 st century. 3 Biotech 6(174): 1-15.

Snowdon, J.A. \& Cliver, D.O. 1996. Microorganisms in honey. International Journal of Food Microbiology 31(1-3): 1-26.

Souza, B.D.A., Alves, R.M.D.O. \& Carvalho, C.A.L.D. 2007. Nest architecture diagnosis of Oxytrigona tataira (Smith, 1863) (Hymenoptera: Meliponinae). Biota Neotropica 7(2): 83-86.

Souza, R.C.S., Yuyama, L.K.O., Aguiar, J.P.L. \& Oliveira, F.P.M. 2004. Nutritional value of honey and pollen of stingless bees of the Amazonian region. Acta Amazonica 34(2): 333-336.

Tajabadi, N., Mardan, M., Saari, N., Mustafa, S., Bahreini, R. \& Manap, M.Y.A. 2013. Identification of Lactobacillus plantarum, Lactobacillus pentosus and Lactobacillus fermentum from honey stomach of honeybee. Brazilian Journal of Microbiology 44(3): 717-722.

Teixeira, A.C., Marini, M.M., Nicoli, J.R., Antonini, Y., Martins, R.P., Lachance, M.A. \& Rosa, C.A. 2003. Starmerella meliponinorum sp. nov., a novel ascomycetous yeast species associated with stingless bees. International Journal of Systematic and Evolutionary Microbiology 53(1): 339-343.

Vasquez, A. \& Olofsson, T.C. 2009. The lactic acid bacteria involved in the production of bee pollen and bee bread. Journal of Apicultural Research 48(3): 189-195.

Vásquez, A., Forsgren, E., Fries, I., Paxton, R.J., Flaberg, E., Szekely, L. \& Olofsson, T.C. 2012. Symbionts as major modulators of insect health: Lactic acid bacteria and honeybees. PLOS ONE 7(3): e33188.

Vásquez, A., Olofsson, T.C. \& Sammataro, D. 2009. A scientific note on the lactic acid bacterial flora in honeybees in the USA - A comparison with bees from Sweden. Apidologie 40(1): 26-28.

Wagh, V.D. 2013. Propolis: A wonder bees product and its pharmacological potentials. Advances in Pharmacological Sciences 2013: Article ID. 308249.

Wang, H., Yang, L., Ping, Y., Bai, Y., Luo, H., Huang, H. \& Yao, B. 2016. Engineering of a Bacillus amyloliquefaciens strain with high neutral protease producing capacity and optimization of its fermentation conditions. PLoS ONE 11(1): e0146373.

Wang, M., Zhao, W.Z., Xu, H., Wang, Z.W. \& He, S.Y. 2015. Bacillus in the guts of honey bees (Apis mellifera; Hymenoptera: Apidae) mediate changes in amylase values. European Journal of Entomology 112(4): 619-624.

White, J.W. \& Maher, J. 1953. Transglucosidation by honey invertase. Archives of Biochemistry and Biophysics 42(2): 360-367.

Wille, A. 1983. Biology of the stingless bees. Annual Review of Entomology 28(1): 41-64.

Wu, L., Wu, H., Chen, L., Yu, X., Borriss, R. \& Gao, X. 2015. Difficidin and bacilysin from Bacillus amyloliquefaciens FZB42 have antibacterial activity against Xanthomonas oryzae rice pathogens. Scientific Reports 5: 1-9.

Yaacob, S.N.S., Huyop, F., Ibrahim, R.K.R. \& Wahab, R.A. 2018. Identification of Lactobacillus spp. and Fructobacillus spp. isolated from fresh Heterotrigona itama honey and their antagonistic activities against clinical pathogenic bacteria. Journal of Apicultural Research 57(3): 395-405.
Ye, M., Sun, L., Yang, R., Wang, Z. \& Qi, K. 2017. The optimization of fermentation conditions for producing cellulase of Bacillus amyloliquefaciens and its application to goose feed. Royal Society Open Science 4(10): 171012.

Yoshiyama, M. \& Kimura, K. 2009. Bacteria in the gut of Japanese honeybee, Apis cerana japonica, and their antagonistic effect against Paenibacillus larvae, the causal agent of American foulbrood. Journal of Invertebrate Pathology 102(2): 91-96.

Yuan, J., Raza, W., Shen, Q. \& Huang, Q. 2012. Antifungal activity of Bacillus amyloliquefaciens NJN-6 volatile compounds against Fusarium oxysporum f. sp. cubense. Applied and Environmental Microbiology 78(16): 5942-5944.

Zhao, P., Quan, C., Wang, Y., Wang, J. \& Fan, S. 2014. Bacillus amyloliquefaciens Q-426 as a potential biocontrol agent against Fusarium oxysporum f. sp. spinaciae. Journal of Basic Microbiology 54(5): 448-456.

Zhao, X., Zhou, Z.J., Han, Y., Wang, Z.Z., Fan, J. \& Xiao, H.Z. 2013. Isolation and identification of antifungal peptides from Bacillus BH072, a novel bacterium isolated from honey. Microbiological Research 168(9): 598-606.

Mohamad Syazwan Ngalimat, Raja Noor Zaliha Raja Abd Rahman, Amir Syahir Amir Hamzah \& Suriana Sabri*

Enzyme and Microbial Technology Research Center

Faculty of Biotechnology and Biomolecular Sciences

Universiti Putra Malaysia

43400 UPM Serdang, Selangor Darul Ehsan

Malaysia

Mohamad Syazwan Ngalimat, Raja Noor Zaliha Raja Abd Rahman, Mohd Termizi Yusof \& Suriana Sabri*

Department of Microbiology

Faculty of Biotechnology and Biomolecular Sciences

Universiti Putra Malaysia

43400 UPM Serdang, Selangor Darul Ehsan

Malaysia

Amir Syahir Amir Hamzah

Department of Biochemistry

Faculty of Biotechnology and Biomolecular Sciences

Universiti Putra Malaysia

43400 UPM Serdang, Selangor Darul Ehsan

Malaysia

Norhasnida Zawawi

Department of Food Science

Faculty of Food Science and Technology

Universiti Putra Malaysia

43400 UPM Serdang, Selangor Darul Ehsan

Malaysia

Norhasnida Zawawi

Laboratory of Molecular Biomedicine

Institute of Bioscience

Universiti Putra Malaysia

43400 UPM Serdang, Selangor Darul Ehsan

Malaysia

*Corresponding author; email: suriana@upm.edu.my

Received: 2 April 2019

Accepted: 25 March 2020 